\title{
The potential of Bacillus strains isolated from the rumen content of dairy cows as natural antibacterial and antioxidant agents for broilers
}

\author{
S. Sugiharto*, T. Yudiarti, I. Isroli, E. Widiastuti, H.I. Wahyuni and E. Suprijatna \\ Faculty of Animal and Agricultural Sciences, Diponegoro University, Semarang \\ *Corresponding E-mail:sgh_undip@yahoo.co.id \\ Received December 14, 2017; Accepted February 21, 2018
}

\begin{abstract}
ABSTRAK
Penelitian dilaksanakan untuk mengetahui aktivitas antibakteri dan efek peningkatan antioksidan dari beberapa strain Bacillus yang diisolasi dari isi rumen sapi perah. Aktivitas antibakteri dari Bacillus terhadap bakteri Escherichia coli ditentukan berdasarkan metode difusi sumuran (agar-well diffusion method). Untuk menentukan efek peningkatan antioksidan, empat strain Bacillus dicampur (disiapkan sebagai multi-strain/mixed-Bacillus) dan digunakan untuk memfermentasi limbah obat herbal (LOH). Efeknya kemudian dibandingkan dengan efek fermentasi dari probiotik komersial Bacillus subtilis pada LOH dan LOH yang tidak difermentasi. Hasil penelitian menunjukkan bahwa setiap strain Bacillus mampu menghambat pertumbuhan E. coli. Fermentasi dengan mixed-Bacillus cenderung $(\mathrm{P}=0,07)$ meningkatkan aktivitas antioksidan dan kandungan total fenol pada LOH. Sebaliknya, fermentasi dengan Bacillus subtilis komersial cenderung $(\mathrm{P}=0,07)$ menurunkan aktivitas antioksidan dan total fenol LOH. Fermentasi dengan kedua starter Bacillus meningkatkan $(\mathrm{P}<0,05)$ kandungan protein kasar dan abu pada $\mathrm{LOH}$, sedangkan lemak kasar meningkat $(\mathrm{P}<0,05)$ pada $\mathrm{LOH}$ yang difermentasi dengan Bacillus subtilis. Fermentasi baik dengan Bacillus subtilis ataupun mixed-Bacillus meningkatkan $(\mathrm{P}<0,05)$ kandungan serat kasar LOH. Sebagai kesimpulan, strain Bacillus yang diisolasi dari isi rumen sapi perah menunjukkan aktivitas antibakteri dan efek peningkatan antioksidan pada LOH sehingga berpotensi sebagai aditif pakan yang dapat menggantikan peran antibiotik dan antioksidan sintetis pada ayam yang dipelihara di daerah panas.
\end{abstract}

Kata kunci: antibakteri, antioksidan, Bacillus, fermentasi, limbah obat herbal

\section{ABSTRACT}

The study was conducted to investigate the in vitro antibacterial activity and antioxidant-enhancing effect of Bacillus strains isolated from the rumen content of dairy cows. The antibacterial activity of Bacillus strains was assessed against Escherichia coli based on the agar-well diffusion method. To assess the antioxidant-enhancing effect, the Bacillus strains was mixed (prepared as multi-strains) and used to ferment herbal medicine waste (HMW). The effect was compared with that of commercial probiotic Bacillus subtilis and non fermented HWM. Results showed that each Bacillus strain was able to inhibit the growth of E. coli. Fermentation with mixed Bacillus strains tended $(\mathrm{P}=0.07)$ to enhance the 2,2-diphenylpicrylhydrazyl (DPPH) radicals scavenging activity and total phenolics content of HMW. In contrast, fermentation with commercial Bacillus subtilis tended $(\mathrm{P}=0.07)$ to decrease DPPH radical scavenging activity and total phenol of HMW. Fermentation with both Bacillus preparations increased $(\mathrm{P}<0.05)$ the contents of crude protein and ash in HMW, while crude fat increased $(\mathrm{P}<0.05)$ in HMW fermented with Bacillus subtilis. Fermentation either with Bacillus subtilis or mixed Bacillus strains 
increased $(\mathrm{P}<0.05)$ the fiber content of HMW. In conclusion, Bacillus strains isolated from the rumen content of dairy cows showed antibacterial activity and antioxidant-enhancing effect, therefore, they are potential as feed additive to substitute synthetic antibiotics and antioxidants for broilers raised under tropical conditions.

Keywords: Antibacterial, antioxidant, Bacillus, fermentation, herbal medicine waste

\section{INTRODUCTION}

Broiler industry has grown substantially over the last decade in Indonesia. As a tropical country, high temperature is one of the most crucial factors in Indonesian broiler industry. Exposure to hot temperature may cause heat stress leading to performance and health problems in broiler chicks (Sugiharto et al., 2017a). Heat stress may shift the normal microbial balance (increased the population of pathogenic bacteria) leading to the changes in intestinal morphology and integrity. The latter condition implies in the impairment of digestive and immunological functions of broiler intestine (Sugiharto et al., 2017a; Sugiharto et al., 2017b). It has commonly been practiced to use infeed antibiotics to control intestinal pathogenic bacterial populations and improve growth performance in poultry reared under heat stress conditions (Sandikci et al., 2004; Rahimi and Khaksefidi, 2006). Also, synthetic antioxidants have been used to ameliorate the detrimental effects of heat stress (oxidative stress) especially on the defence system of chicks (Sugiharto et al., 2017b). It should, however, be noted that longterm administration of in-feed antibiotics and synthetic antioxidants may leave residues in broiler meats, which can risk human health. Indeed, the residue of antibiotics in broiler meat may cause antibiotic resistance (Sugiharto, 2016), while synthetic antioxidants can induce carcinogenic effect on humans (Blaszczyk et al., 2013; Abreu et al., 2015). Owing to this fact, any alternatives to substitute the role of in-feed antibiotics and synthetic antioxidants are essential for broiler production in the tropical countries.

Among the in-feed antibiotics substitutes, probiotic microorganisms have received the most attention from poultry nutritionists (Sugiharto, 2016). In most circumstances, probiotics are isolated from the host gastrointestinal tract. However, there has been a recent trend to use probiotic microorganisms isolated from another animal species (Puspani et al., 2016) and other unconventional sources (Sornplang et al., 2016). It has been known that rumen contains a huge numbers of microorganisms that provide benefits not only for the host but also for other farm animals (Fraga et al., 2014). Considering the above facts, in the earlier study, some Bacillus strains from the rumen content of dairy cows have been isolated and identified (unpublished data). Yet, the functional properties of these isolates remained unelucidated so far. In the present study, these Bacillus strains were investigated for their antibacterial activity. The latter property is crucial to control the pathogenic bacteria populations in the intestine of heat-stressed birds. Recently, there has been a considerable interest to use Bacillus spp., not only for probiotics, but also for enhancing the antioxidant properties of feed ingredients through fermentation. Juan et al. (2010) reported an enhancement of antioxidant activity, total phenolic and flavonoid content of black soybeans following fermentation with Bacillus subtilis BCRC 14715. Concomitantly, Sanjukta et al. (2015) showed enhanced antioxidant properties of soybean after fermentation with Bacillus subtilis. It should, however, be noted that the effect of Bacillusfermentation on antioxidant activities is species/strain- and substrate-specific, as Yoon et al. (2015) reported a reduced antioxidant activity in black rice bran after fermentation with Bacillus subtilis KU3.

Herbal products have traditionally been used for human medicine for centuries. At recent times, herbal products have also been employed as antibacterial/anti coccidial agents (Muthamilselvan et al., 2016) as well as for antioxidant source for poultry (Wang et al., 2008). However, the use of herbal products for broiler production seems impractical as it has to compete with the human (Elfahmi et al., 2014). In the recent years, herbal medicine industries have been growing considerably in Indonesia. Apart from the herbal medicine products (for human consumption), the industries produce a large amount of waste that may raise environmental problems (Soetrisnanto et al., 2012). Indeed, although in limited quantities, most of HMW still contains phenols, flavonoids and tannins that are antioxidant components (Kisworo et al., 2016). Through Bacillus-fermentation, the antioxidant 
properties of HMW were therefore expected to be increased and, eventually, can efficiently be used as natural antioxidants for broiler. The objective of the present study was to investigate the in vitro antibacterial activity and antioxidant-enhancing effect of mixed Bacillus strains isolated from the rumen content of dairy cows. In this study, the Bacillus strains were prepared in mixed-/multistrains (instead of single-strain) when being used as a fermentation starter of HMW. This was actually inspired by data from the in vivo study suggesting that multi-strains Bacillus are more effective than single-strain in exerting beneficial effects (Chang et al., 2017).

\section{MATERIALS AND METHODS}

\section{In vitro Antibacterial Activity of Bacillus Strains}

The antibacterial activity of Bacillus strains, isolated from the rumen content of dairy cows, against Escherichia coli ATCC 25922 was conducted according to the agar-well diffusion method (Yilmaz et al., 2006) with few modifications. In brief, nutrient agar (Merck $\mathrm{KGaA}$, Darmstadt, Germany) was poured into sterile Petri dish and once the agar was solidified, it was then punched with a six millimetres diameter wells. The Bacillus strains (i.e., Bacillus cereus strain SIIA_Pb_E3, Bacillus licheniformis strain FJAT-29133, Bacillus megaterium strain F4-2-27 and Bacillus sp.11CM31Y12) and $E$. coli were cultured separately in nutrient broth (Merck KGaA) and incubated aerobically at $38^{\circ} \mathrm{C}$ for 24 hours. After the centrifugation at $6,000 \mathrm{~g}$ for $15 \mathrm{~min}$, the supernatant of each Bacillus strain was obtained. The suspension of E. coli $(100 \mu \mathrm{L})$ was spread on the plates, and the supernatant of Bacillus strains $(20 \mu \mathrm{L})$ was filled into the wells of agar plates. The plates were incubated aerobically at $38^{\circ} \mathrm{C}$ for 24 hours, and the diameter of the inhibition zone was determined using callipers. The assays were conducted in duplicate.

\section{Fermentation of Herbal Medicine Waste}

In this study, fermentation of HMW was conducted either with commercial probiotic Bacillus subtilis or mixed Bacillus strains as tested above. The unfermented HMW was used as a control. The probiotic Bacillus subtilis concentrate (contained $1 \times 10^{22} \mathrm{cfu} / \mathrm{g}$ ) was obtained from PT. Bayer Indonesia (Jakarta, Indonesia). The mixed Bacillus strains consisted of $6.5 \times 10^{12}, 2.4 \times 10^{11}, 2.6 \times 10^{13}$ and $1.7 \times 10^{13}$ cfu/g for Bacillus cereus strain SIIA_Pb_E3, Bacillus licheniformis strain FJAT-29133, Bacillus megaterium strain F4-2-27 and Bacillus sp.11CM31Y12, respectively. Zeolite was used as a carrier for the bacteria.

The HMW used in the present study was obtained from PT. Sidomuncul, Tbk. (Semarang, Central Java, Indonesia). It was the by-products of "Tolak Angin" herbal medicine composing of Foeniculli fructus, Isorae fructus, Caryophylli folium, Zingiberis Rhizoma, Menthae arvensis Herba, Phyllanthi Herba, Mel depuratum, Myristicae semen, Amomi fructus, Centellae Herba, Parkiae semen and Oryza sativa. Following sterilization (using autoclave at $121^{\circ} \mathrm{C}$ for $15 \mathrm{~min}$ ), $500 \mathrm{~g}$ of HMW was inoculated either with $1 \%$ of probiotic Bacillus subtilis concentrate or mixed Bacillus strains preparation. The mixture was then soaked with sterile water $(1: 1)$, mixed thoroughly, and incubated for four days and turned every two days. The rest of HMW was not fermented, and used as a control. The experiment was conducted in triplicate. Fermented samples were obtained for the determination of antioxidant activity and proximate compositions.

\section{Determination of Antioxidant Activity}

The determination of the 2,2diphenylpicrylhydrazyl (DPPH) free radical scavenging activity of the samples was conducted according to Brighente et al. (2007) with few modifications. In brief, samples from the Bacillusfermentation and control were macerated before analysis. Maceration was conducted by dissolving $0.1 \mathrm{~g}$ of fermented HMW in $1 \mathrm{~mL}$ ethanol. The mixture was sonicated and centrifuged at 6,000 rpm for 5 minutes, and the supernatant was then obtained for analysis. The supernatant $(0.5 \mathrm{~mL})$ was added to $2.5 \mathrm{~mL}$ of a solution of DPPH radicals in methanol. The mixture was shaken and let to stand for 30 minutes at room temperature. The absorbance was measured at $517 \mathrm{~nm}$. The radical scavenging activity of the sample was expressed as $\mathrm{IC}_{50}$ value. The following formula was used to determine the scavenging capability of DPPH radicals:

$$
\text { Inhibition }(\%)=[1-(\mathrm{AS} / \mathrm{ANS})] \times 100
$$

Where AS was the absorbance of DPPH solution with sample and ANS was the absorbance of DPPH solution without sample. The assays were conducted in triplicates.

\section{Determination of Total Phenolics}

Total phenolics content of fermented and 
unfermented HMW was determined according to Folin-Ciocalteu method (Sugiharto et al., 2016) with few modifications. The supernatant as prepared above $(0.5 \mathrm{~mL})$, distilled water $(8 \mathrm{~mL})$, Folin-Ciocalteu reagent $(0.5 \mathrm{~mL}$, Merck KGaA) and sodium carbonate $\left(\mathrm{Na}_{2} \mathrm{CO}_{3}, 1 \mathrm{~mL}\right.$, Merck $\mathrm{KGaA}$ ) were mixed, and incubated at room temperature for 30 minutes. Using spectrophotometer, the absorbance of the solution was measured at $765 \mathrm{~nm}$. A standard curve was subsequently plotted using gallic acid. The assays were performed in triplicate.

\section{Determination of Total Tannins}

The determination of total tannins in fermented and unfermented HMW was based on colorimetric method using Folin-Denis reagent (Chanwitheesuk et al., 2005). Briefly, supernatant from the fermented or unfermented HMW (0.5 $\mathrm{mL}$ ) was added with $8 \mathrm{~mL}$ distilled water, $0.5 \mathrm{~mL}$ Folin-Denis reagent (Merck $\mathrm{KGaA}$ ) and $1 \mathrm{~mL}$ sodium carbonate $\left(\mathrm{Na}_{2} \mathrm{CO}_{3}\right)$. The mixture was homogenized thoroughly and incubated at room temperature for 30 minutes. The absorbance of the solution was then measured at $760 \mathrm{~nm}$ using tannic acid solution (Sigma-Aldrich) as a standard solution. The assays were carried out in triplicate.

\section{Proximate Analysis}

The samples of fermented HMW were analysed for proximate compositions based on the methods of the Association of Official Analytical Chemists (AOAC, 2005). The crude protein content was determined based on Kjeldahl method, while the crude fat was based on Soxhlet extraction method. The digestion method was employed to determine the crude fiber content. The content of ash in the samples was determined by ashing the samples at $550^{\circ} \mathrm{C}$ for 3 hours. The analyses were carried out in triplicate.

\section{Data Analysis}

The data on antibacterial activity of each Bacillus strain were not statistically analysed. The data of DPPH radical scavenging activity, total phenolic, tannin contents and proximate composition of fermented HMW were analysed by analysis of variance (ANOVA) using the general linear models procedure in SAS (SAS Inst. Inc., Cary, NC, USA). Significant differences $(\mathrm{P}<0.05)$ among treatment groups were further analysed using Duncan's multiple range test.

\section{RESULTS}

\section{Antibacterial Activity of Bacillus strains}

The antibacterial activity of each Bacillus strain against $E$. coli was represented by the diameter of the inhibition zone (Table 1 and Figure 1). It was apparent that each Bacillus strain was able to inhibit the growth of $E$. coli.

\section{DPPH Radical Scavenging Activity, Total phenolic and Tannin Contents in Fermented HMW}

Data on DPPH radical scavenging activity, total phenolics and tannin contents in HMW are presented in Table 2. Fermentation with mixed Bacillus strains tended to enhance the antioxidant activity and total phenolics in HMW. Conversely, fermentation with commercial Bacillus subtilis tended to decrease DPPH radical scavenging activity and total phenolin HMW. The effect of Bacillus-fermentation was not significant in term of tannin contents in HMW.

\section{Proximate Compositions of Fermented HMW}

The data on chemical compositions of fermented HMW are presented in Table 3. Fermentation with both Bacillus preparations increased $(\mathrm{P}<0.05)$ the contents of crude protein and ash in HMW, while crude fat increased $(\mathrm{P}<0.05)$ in HMW fermented with Bacillus subtilis. Fermentation either with Bacillus subtilis or mixed Bacillus strains increased $(\mathrm{P}<0.05)$ the fiber content of HMW.

\section{DISCUSSION}

In response to the ban of in-feed antibiotics in broiler production, nutritionists are now searching for safer alternative feed additives for broiler chickens. Although probiotics has been considered the safest and most promising alternative, the efficacy of such additive on broiler health and performance is variable depending on the species and strains of the probiotic microorganisms (Sugiharto, 2016). In this reason, the search for more effective and consistent probiotic microorganism is still necessary to support the sustainable broiler production especially in the tropical countries. In the earlier study, some strains of Bacillus from the rumen content of dairy cows have been isolated and identified. To follow up, this present study investigated an in vitro antibacterial activity, which is one of the most important probiotic 
Table 1. Diameters of Inhibition Zone Exhibited by Bacillus Strains Against E. coli ${ }^{\text {a }}$

\begin{tabular}{lc}
\hline \multicolumn{1}{c}{ Bacillus strains } & Diameters of inhibition zone (mm) \\
\hline Bacillus cereus strain SIIA_Pb_E3 & $11.3 \pm 0.45$ \\
Bacillus licheniformis strain FJAT-29133 & $12.7 \pm 0.67$ \\
Bacillus megaterium strainF4-2-27 & $13.3 \pm 0.35$ \\
Bacillus sp.11CM31Y12 & $12.5 \pm 0.47$ \\
\hline
\end{tabular}

${ }^{\mathrm{a}}$ Values are mean $\pm \mathrm{SD}$
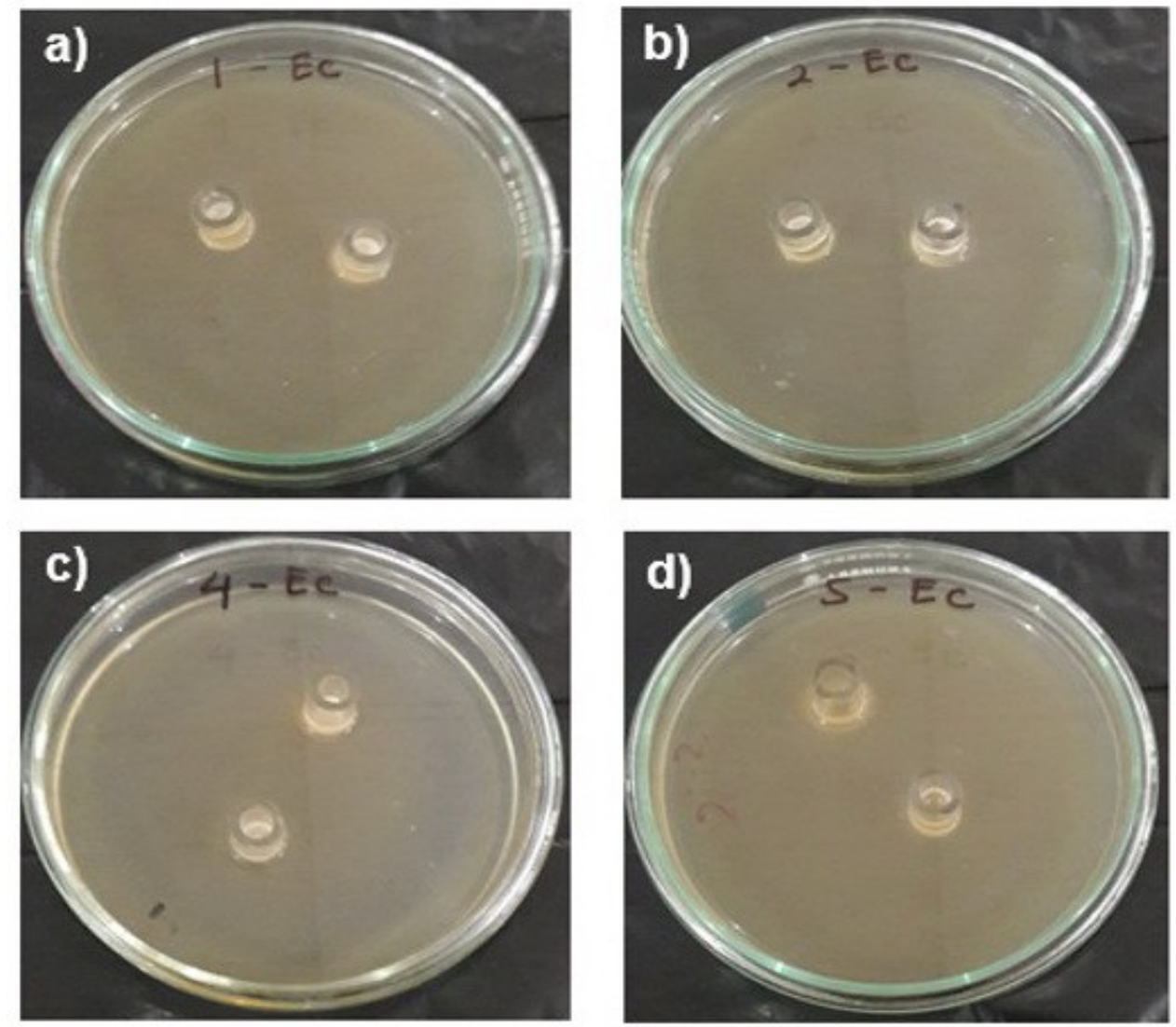

Figure 1. The inhibition zone exhibited by Bacillus strains against E. coli; a) Bacillus cereus strain SIIA_Pb_E3, b) Bacillus licheniformis strain FJAT-29133, c) Bacillus megaterium strainF4-2-27, and d) Bacillus sp.11CM31Y12

properties, of these Bacillus strains. It was apparent in our result that four isolates of Bacillus strains were able to inhibit the growth of E. coli. Concomitant with our results, Yilmaz et al. (2006) in the previous study showed the antibacterial activity of some Bacillus spp. strains isolated from the soil against both Gram-positive and
Gram-negative bacteria. The antibacterial activity of Bacillus species was also reported by Amin et al. (2015) against Staphylococcus aureus (PTCC 1112), Shigella dysenteriae (PTCC 1188), E. coli (PTCC 1396), salmonella typhi (PTCC 1609), and Corynebacterium diphtheriae (ATCC 27010). The mechanism through which our isolates inhibited 
Table 2. DPPH Radical Scavenging Activity, Total Phenolic and Tannin Contents in HMW Fermented by Different Starters ${ }^{\mathrm{a}}$

\begin{tabular}{lccc}
\hline Starters & $\begin{array}{c}\mathrm{IC}_{50}{ }^{\mathrm{b}} \\
(\mu \mathrm{g} / \mathrm{mL})\end{array}$ & $\begin{array}{c}\text { Total phenolics } \\
(\mathrm{mg} / 100 \mathrm{~g})\end{array}$ & $\begin{array}{c}\text { Total tannins } \\
(\mathrm{mg} / 100 \mathrm{~g})\end{array}$ \\
\hline Control & $262 \pm 64.4$ & $12.2 \pm 4.50$ & $5.60 \pm 0.89$ \\
Bacillus subtilis & $314 \pm 18.0$ & $6.40 \pm 0.30$ & $5.23 \pm 0.21$ \\
Mixed Bacillus strains & $197 \pm 2.81$ & $14.5 \pm 0.70$ & $6.37 \pm 0.94$ \\
\hline
\end{tabular}

${ }^{\mathrm{a}}$ Values are mean $\pm \mathrm{SD}$

${ }^{\mathrm{b}} \mathrm{IC}_{50}$ is identified as the effective concentration at which the 2,2-diphenylpicrylhydrazyl (DPPH) radicals were scavenged by about $50 \%$. A higher of DPPH radical scavenging activity is associated with a lower $\mathrm{IC}_{50}$ value.

Table 3. Chemical Composition of HMW Fermented by Different Starters (as Dry Matter Basis) ${ }^{\mathrm{a}}$

\begin{tabular}{lcccc}
\hline Starters & Crude protein (\%) & Crude fat (\%) & Crude fiber (\%) & Ash (\%) \\
\hline Control & $10.7 \pm 0.10^{\mathrm{b}}$ & $2.81 \pm 0.13^{\mathrm{b}}$ & $22.8 \pm 0.49^{\mathrm{c}}$ & $4.97 \pm 0.19^{\mathrm{c}}$ \\
Bacillus subtilis & $11.5 \pm 0.47^{\mathrm{a}}$ & $3.83 \pm 0.55^{\mathrm{a}}$ & $28.2 \pm 0.51^{\mathrm{a}}$ & $5.96 \pm 0.29^{\mathrm{a}}$ \\
Mixed Bacillus strains & $11.3 \pm 0.27^{\mathrm{a}}$ & $3.15 \pm 0.24^{\mathrm{b}}$ & $26.2 \pm 0.89^{\mathrm{b}}$ & $5.47 \pm 0.17^{\mathrm{b}}$ \\
\hline
\end{tabular}

${ }^{a}$ Values are mean \pm SD

the growth of E. coli was not clear, but Amin et al. (2015) proposed that bacitracin produced by Bacillus spp. may be responsible as antibacterial substances. Taking this finding into the consideration, the Bacillus strains in this study may therefore be employed as natural antibacterial agents that can substitute the role of in-feed antibiotics in broiler rations.

As mentioned earlier, administration of synthetic antioxidants to broiler chickens has been attributed to the potential carcinogenic effect on humans as consumers (Blaszczyk et al., 2013; Abreu et al., 2015). With food safety reason, broiler farmers are now encouraged to use natural antioxidants to protect the birds from the detrimental effects of oxidative stress (Sugiharto et al., 2017a), one of which is herbal products (Wang et al., 2008). However, the use of such products for broilers may compete with the human need for medicine (Elfahmi et al., 2014). Considering the continuous production of HMW in Indonesia and the antioxidant properties in
HMW, the present study aimed to increase the antioxidant properties of HWM through Bacillusfermentation. Indeed, our present data showed that fermentation with mixed Bacillus strains tended to increase the antioxidant activity of HMW. This finding was in accordance with Juan et al. (2010) showing an enhancement of antioxidant activity, total phenolic and flavonoid content in black soybeans following fermentation with Bacillus subtilis BCRC 14715. Conversely, fermentation with commercial Bacillus subtilis tended to lower antioxidant activity of HMW in the current study. Corresponding to this, Yoon et al. (2015) reported that fermentation with Bacillus subtilis KU3 reduced antioxidant activity in black rice bran. In these regards, this study confirmed that the effect of Bacillus-fermentation on the antioxidant properties was species- and strain-specific (and perhaps substrate-specific). In the case of the enhanced antioxidant activity after fermentation (with mixed Bacillus strains), such bacterial fermentation may increase the 
production and release of phenolic compounds with high antioxidant activity (Yao et al., 2010). This inference was supported by the fact that fermentation with mixed Bacillus strains increased the content of total phenolics in HMW. In nature, phenolic compounds are bound with sugar, and during fermentation these complex components were degraded into free phenols with high antioxidant properties (Adetuyi and Ibrahim, 2014). In addition to phenolic compounds, the enhanced antioxidant activity in mixed Bacillus strains-fermented HMW may be attributed to the increased total tannins in HMW (though the values were not statistically significant). Note that tannin may contribute to the antioxidant capacity of materials (Sugiharto et al., 2016). Overall, fermentation with mixed Bacillus strains could be the method to optimize the use of HMW as natural antioxidant sources for broiler chickens raised under hot ambient temperature.

As mentioned earlier, fermentation with commercial Bacillus subtilis tended to decrease DPPH radical scavenging activity and total phenols in HMW. The definite explanation for the decreased antioxidant activity in commercial Bacillus subtilis-fermented HMW was not known, but the degradation of phenolic compounds during fermentation with Bacillus subtilis may be one of the reasons (Paliyath et al., 2011). Note that phenolics are reactive compounds that may be destructed by enzymatic and/or non-enzymatic reactions during fermentation process (Hunaefi and Smetanska, 2013). With regard to Bacillus subtilis, Hasan and Jabeen (2015) reported that inoculation with Bacillus subtilis isolated from soil was able to degrade phenol in culture medium. Concomitantly, Nair and Prakash (2017) showed the capability of Bacillus subtilis SP3 in degrading phenolic compounds in vitro.

Recently, there has been a considerable interest to produce functional feeds by fermenting the feed or feed ingredients using selected probiotic microorganisms (Sugiharto et al., 2015; 2017 c). In such case, fermented products may not only rich in probiotics and their metabolite products, but also having improved nutritional values. In the present study, fermentation with both mixed Bacillus strains and commercial Bacillus subtilis increased the contents of crude protein and ash in HMW, while crude fat increased only in HMW fermented with Bacillus subtilis. This finding was in accordance with that of reported by Wongputtisin et al. (2014) showing the increased crude protein and ash contents in soya bean hull after fermentation with Bacillus subtilis. Concomitantly, Bacillus amyloliquefaciens-fermentation increased the contents of crude protein in rice bran (Supriyati et al., 2015) and Bacillus sphaericus-fermentation increased the fat content of soybean (Jeff-Agboola and Oguntuase, 2006). Bacillus-fermentation may, therefore, result in product (fermented HMW) that can supply the nutrients to broiler chickens, in addition to the supply of functional components such as antibacterials and antioxidants as discussed earlier. In contrast to Supriyati et al. (2015), Bacillus-fermentation increased the fiber content of HMW in the present study. However, our finding was concomitant with Jeff-Agboola and Oguntuase (2006) and Wongputtisin et al. (2014) showing an increased fiber content of soybean and soya bean hull after fermentation with Bacillus sphaericus and Bacillus subtilis, respectively. The definite reason for the increased fiber content in fermented HWM was not clear so far. In the study of Jeff-Agboola and Oguntuase (2006), the increased fiber was accompanied by the decreased carbohydrate content in soybean. This may suggest that fermentation degraded the complex carbohydrate (polysaccharides) into simpler fiber (oligosaccharides), resulting in the increase and decrease in crude fiber and carbohydrate contents, respectively.

\section{CONCLUSION}

It could be concluded that Bacillus strains isolated from the rumen content of dairy cows had antibacterial property and antioxidant-enhancing effect. It was, therefore, possible to use these Bacillus strains as feed additive to substitute the role of synthetic antibiotics and antioxidants for broiler chickens, especially those are raised under tropical conditions.

\section{ACKNOWLEDGEMENTS}

The study was funded by Directorate of Research and Community Service, the Ministry of Research, Technology and Higher Education of the Republic of Indonesia through "Penelitian Unggulan Perguruan Tinggi" No. 007/SP2H/LT/DRPM/2017, 5 May 2017. Special thanks to PT. Sidomuncul, Tbk. that provided herbal medicine waste and PT. Bayer Indonesia that provided probiotic Bacillus subtilis. 


\section{REFERENCES}

Abreu, V.K.G., A.L.F. Pereira, E.R. de Freitas, M.T.S. Trevisan and J.M.C. da Costa. 2015. Addition of anacardic acid as antioxidants in broiler chicken mortadella. Food Sci. Technol. 35:539-545.

Adetuyi, F.O. and T.A. Ibrahim. 2014. Effect of fermentation time on the phenolic, flavonoid and vitamin $\mathrm{C}$ contents and antioxidant activities of okra (Abelmoschus esculentus) seeds. Nigerian Food J. 32:128137.

Amin, M., Z. Rakhisi and A.Z. Ahmady. 2015. Isolation and identification of Bacillus species from soil and evaluation of their antibacterial properties. Avicenna J. Clin. Microbiol. Infect. 2:1-4.

AOAC. 2005. Official methods of analysis. In: W. Horowitz, Editor, Official methods of analysis (17th ed.), Association of Official Analytical Chemists, Gaithersburg, USA.

Baszczyk, A., A. Augustyniak and J. Skolimowski. 2013. Ethoxyquin: an antioxidant used in animal feed. Int. J. Food Sci. 2013:1-12.

Brighente, I.M.C., M. Dias, L.G. Verdi, and M.G. Pizzolatti. 2007. Antioxidant activity and total phenolic content of some Brazilian species. Pharm. Biol. 45:156-161.

Chang, H.Y., J.H. Chen, J.H. Chang, H.C. Lin and C.C. Ping. 2017. Multiple strains probiotics appear to be the most effective probiotics in the prevention of necrotizing enterocolitis and mortality: An updated meta-analysis. Plos One. 12:1-14.

Chanwitheesuk, A., A. Teerawutgulrag and N. Rakariyatham. 2005. Screening of antioxidant activity and antioxidant compounds of some edible plants of Thailand. Food Chem. 92:491-497.

Elfahmi, H., J. Woerdenbag and O. Kayser. 2014. Jатu: Indonesian traditional herbal medicine towards rational phytopharmacological use. J. Herb. Med. 4: 51-73.

Fraga, M., K. Perelmuter, M.J. Valencia, M. Martínez, A. Abin-Carriquiry, C. Cajarville, and P. Zunino. 2014. Evaluation of native potential probiotic bacteria using an in vitro ruminal fermentation system. Ann. Microbiol. 64:1149-1156.

Hasan, S.A. and S. Jabeen. 2015. Degradation kinetics and pathway of phenol by Pseudomonas and Bacillus species. Biotechnol. Biotechnolog. Equip. 29:45-53.

Hunaefi, D. and I. Smetanska. 2013. The effect of tea fermentation on rosmarinic acid and antioxidant properties using selected in vitro sprout culture of Orthosiphon aristatus as a model study. SpringerPlus. 2:1-14.

Jeff-Agboola, Y.A. and O.S. Oguntuase. 2006. Effect of Bacillus sphaericus on proximate composition of soybean (Glycine max) for the production of soy iru. Pak. J. Nutr. 5:606-607.

Juan, M.Y. and C.C. Chou. 2010. Enhancement of antioxidant activity, total phenolic and flavonoid content of black soybeans by solid state fermentation with Bacillus subtilis BCRC 14715. Food Microbiol. 27:586-591.

Kisworo, A.N., A. Agus, Kustantinah and B. Suwignyo. 2016. Physicochemical characteristics identification and secondary metabolite analysis of solid herbal waste as source of feed rich fiber and supplement for ruminants. Anim. Prod. 18:75-84.

Muthamilselvan, T., T.F. Kuo, Y.C. Wu and W.C. Yang. 2016. Herbal remedies for coccidiosis control: a review of plants, compounds, and anticoccidial actions. Evidence-Based Complement. Alternat. Med. 2016:1-19

Nair, I.C. and S. Prakash. 2017. Degradation of phenol using a PHB producing Bacillus subtilis SP3. World J. Pharm. Res. 6:11271142.

Paliyath, G., M. Bakovic and K. Shetty. 2011. Functional foods, nutraceuticals, and degenerative disease prevention. John Wiley $\&$ Sons, Inc. State Avenue, Iowa, USA.

Puspani, P., D.P.M.A. Candrawati and I.G.N.G. Bidura. 2016. Implementation probiotics cellulolitic B-7 bacteria (isolation from buffalo rumen) into rations on the performance, abdominal fat and serum cholesterol of duck. Int. J. Curr. Microbiol. App. Sci.,5:432-441.

Rahimi, Sh. and A. Khaksefidi. 2006. A comparison between the effects of a probiotic (Bioplus 2B) and an antibiotic (virginiamycin) on the performance of broiler chickens under heat stress condition. Iranian J. Vet. Res. Univ. Shiraz. 7:23-28.

Sandikci, M., U. Eren, A.G. Onol, and S. Kum. 2004. The effect of heat stress and the use of Saccharomyces cerevisiae or (and) 
bacitracin zinc against heat stress on the intestinal mucosa in quails. Rev. Méd. Vét. 155:552-556.

Sanjukta, S., A.K. Rai, A. Muhammed, K. Jeyaram and N.C. Talukdar. 2015. Enhancement of antioxidant properties of two soybean varieties of Sikkim Himalayan region by proteolytic Bacillus subtilis fermentation. J. Funct. Foods. 14:650-658.

SAS 1985. SAS user's guide: Statistics, version 5. Cary, NC, USA.

Soetrisnanto, D., M. Christwardana and Hadiyanto. 2012. Application of phytoremediation for herbal medicine waste and its utilization for protein production. Reaktor. 14:129-134.

Sornplang, P. and S. Piyadeatsoontorn. 2016. Probiotic isolates from unconventional sources: a review. J. Anim. Sci. Technol. 58: 26. DOI: 10.1186/s40781-016-0108-2

Sugiharto, S., C. Lauridsen and B.B. Jensen. 2015. Gastrointestinal ecosystem and immunological responses in E. coli challenged pigs after weaning fed liquid diets containing whey permeate fermented with different lactic acid bacteria. Anim. Feed Sci. Technol. 207:278-282.

Sugiharto, S. 2016. Role of nutraceuticals in gut health and growth performance of poultry. J. Saudi Soc. Agric. Sci. 15: 99-111.

Sugiharto, S., T. Yudiarti and I. Isroli. 2016. Assay of antioxidant potential of two filamentous fungi isolated from the Indonesian fermented dried cassava. Antioxidants. 5: 6

Sugiharto, S., T. Yudiarti, I. Isroli, E. Widiastuti and E. Kusumanti. 2017a. Dietary supplementation of probiotics in poultry exposed to heat stress - a review. Ann. Anim. Sci. 17:591-604.

Sugiharto, S., T. Yudiarti, I. Isroli, E. Widiastuti and F.D. Putra. 2017b. Effect of dietary supplementation with Rhizopus oryzae or Chrysonilia crassa on growth performance, blood profile, intestinal microbial population, and carcass traits in broilers exposed to heat stress. Arch. Anim. Breed. 60:347-356.

Sugiharto, S., T. Yudiarti, I. Isroli, E. Widiastuti and F.D. Putra. 2017c. Effects of feeding cassava pulp fermented with Acremonium charticola on growth performance, nutrient digestibility and meat quality of broiler chicks. S. Afr. J. Anim. Sci. 47:130-138.

Supriyati, T. Haryati, T. Susanti and I.W.R. Susana. 2015. Nutritional value of rice bran fermented by Bacillus amyloliquefaciens and humic substances and its utilization as a feed ingredient for broiler chickens. AsianAust. J. Anim. Sci. 28:231-238.

Wang, L., X.L. Piao, S.W. Kim, X. S. Piao, Y.B. Shen and H.S. Lee. 2008. Effects of Forsythia suspensa extract on growth performance, nutrient digestibility, and antioxidant activities in broiler chickens under high ambient temperature. Poult. Sci. 87: 1287-1294.

Wongputtisin, P., C. Khanongnuch, W. Kongbuntad, P. Niamsup, S. Lumyong and P.K. Sarkar. 2014. Use of Bacillus subtilis isolates from Tua-nao towards nutritional improvement of soya bean hull for monogastric feed application. Let. Appl. Microbiol. 59:328-333.

Yao, Q., J. Xiao-nan and P.H. Dong. 2010. Comparison of antioxidant activities in black soybean preparations fermented with various microorganisms. Agric. Sci. China. 9:1065-1071.

Yilmaz, M., H. Sorana and Y. Beyatli. 2006. Antimicrobial activities of some Bacillus spp. strains isolated from the soil. Microbiol. Res. 161:127-131.

Yoon, H.J., K.A. Lee, J.H. Lee, H.J. Jin, H.J. Kim, K.T. Kim and H.D. Paik. 2015. Effect of fermentation by Bacillus subtilis on antioxidant and cytotoxic activities of black rice bran. Int. J. Food Sci. Technol. 50:612618. 